\title{
EVALUASI PENERAPAN SISTEM INFORMASI AKUNTANSI PERSEDIAAN BAHAN BAKU PADA PT. CIOMAS ADISATWA MEDAN
}

\author{
Melky Alessandro Purba, Dimita H. P. Purba, Jamaluddin ${ }^{\bowtie}$, Mulatua P. Silalahi \\ Universitas Methodist Indonesia, Medan, Indonesia \\ Email: jamaluddin@methodist.ac.id
}

DOI: $\underline{\text { https://doi.org/10.46880/jmika.Vol5No1.pp77-80 }}$

\begin{abstract}
This study aims to determine the application of accounting information system for raw material inventories at PT. Ciomas Adisatwa Medan. To find out the application of the accounting system for raw material inventory at PT. Ciomas Adisatwa Medan, data collection techniques were used, namely literature study and field research techniques. While the analysis technique used is a descriptive method. From the results of the study, it can be concluded that application of the accounting information system for raw material inventory at PT. Ciomas Adisatwa Medan has been implemented not good, because there is still inaccurate information that is the demand for raw materials is not in accordance with what is received by the production. Weaknesses Oversight of raw material inventory in warehouses is piling up and is not suitable for processing. The delay in the schedule of order for supporting raw materials to be processed, so the production process does not run properly. The procedures used in the accounting information system for raw material inventory at PT. Ciomas Adisatwa Medan, among others, procedures for requesting raw materials, procedures for receiving raw materials and procedures for issuing raw materials.
\end{abstract}

Keyword: Accounting Information System, Inventory, Raw Material.

\begin{abstract}
ABSTRAK
Penelitian ini bertujuan untuk mengetahui penerapan sistem informasi akuntansi persediaan bahan baku pada PT Ciomas Adisatwa Medan. Untuk mengetahui penerapan sistem informasi akuntansi persediaan bahan baku pada PT. Ciomas Adisatwa Medan, maka digunakan teknik pengumpulan data yaitu teknik studi kepustakaan dan penelitian lapangan. Sedangkan teknik analisis yang digunakan adalah metode deskpritif. Dari hasil penelitian dapat disimpulkan bahwa penerapan sistem informasi akuntansi persediaan bahan baku pada PT. Ciomas Adisatwa Medan sudah diterapkan kurang baik, dikarenakan masih adanya informasi yang kurang akurat yaitu permintaan atas bahan baku tidak sesuai dengan apa yang diterima oleh pihak produksi. Adanya kelemahan Pengawasan terhadap persediaan bahan baku di gudang menumpuk dan tidak layak untuk diolah. Terjadinya keterlambatan jadwal pesanan bahan baku pendukung yang akan diolah, sehingga proses produksi tidak berjalan dengan semestinya. Prosedur-prosedur yang digunakan dalam Sistem Informasi Akuntansi Persediaan Bahan Baku pada PT. Ciomas Adisatwa Medan antara lain prosedur permintaan bahan baku, prosedur penerimaan bahan baku dan prosedur pengeluaran bahan baku.
\end{abstract}

Kata Kunci: Sistem Informasi Akuntansi, Persediaan, Bahan Baku.

\section{PENDAHULUAN}

Sistem informasi akuntansi merupakan sistem yang memproses data dan transaksi guna menghasilkan informasi yang bermanfaat untuk merencanakan, mengendalikan dan mengoperasikan (Romney \& Steinbart, 2015). Dengan adanya sistem informasi akuntansi, maka perusahaan dapat mengontrol dengan baik segala jenis kegiatan yang berhubungan dengan keuangan. Jika sistem informasi akuntansi perusahaan tidak berjalan dengan baik maka akan menyebabkan sistem yang berjalan menjadi terhambat sehingga menyebabkan kegiatan perusahaan tidak berjalan dengan lancar. Maka dari itu, sistem informasi sangat berperan penting bagi perusahaan untuk mengoperasikan aktivitas perusahaan.

Dalam pelaksanaan suatu sistem informasi akuntansi akan tampak jelas pembagian tugas dan wewenang fungsi-fungsi yang terdapat dalam perusahaan sehingga ada pembagian tugas yang jelas diantara fungsi-fungsi yang berkaitan terhadap suatu transaksi dalam perusahaan. Dalam suatu sistem informasi akuntansi terdapat beberapa sub sistem. Salah satu sub sistem tersebut adalah sistem informasi untuk persediaan bahan baku. Sistem informasi 
akuntansi persediaan bahan baku mutlak diperlukan bagi setiap perusahaan manufaktur guna mempermudah kegiatan proses produksi perusahaan tersebut. Karena kegiatan produksi tidak akan berjalan dengan baik tanpa di dukung dengan pengelolaan persediaan bahan baku yang baik.

Adanya sistem informasi yang kurang efektif dapat menimbulkan penyalahgunaan persediaan barang pada perusahaan. Tidak adanya prosedur dan sistem informasi akuntansi penerimaan dan pengeluaran bahan baku yang memadai menyebabkan terjadinya kelebihan pemakaian yang dapat merugikan perusahaan (Mustofa, Lestari, \& Rosyafah, 2015). Sistem infromasi akuntansi persediaan yang diterapkan perusahaan diharapkan dapat memberikan manfaat bagi pimpinan dan manajer perusahaan dalam pengambilan keputusan dan menentukan strategi dalam melaksanakan aktivitas perusahaan. Manajer dapat mengalokasikan sumber daya secara efektif dan efisien, sehingga dibutuhkan suatu pengendalian internal dalam bentuk pengawasan yang dapat memberikan keyakinan bahwa tujuan perusahaan telah tercapai.

Pengendalian internal harus dilaksanakan seefektif mungkin dalam suatu perusahaan untuk mencegah dan menghindari terjadinya kesalahan, kecurangan, dan penyelewengan, maka dibutuhkan penyusunan suatu kerangka pengendalian atas sistem yang sudah ada pada perusahaan. Keterlambatan bahan baku dapat menghambat proses produksi, maka dari itu dibutuhkan pengendalian internal dalam permintaan bahan baku agar tidak terjadinya keterlambatan jadwal pesanan bahan baku, maupun kurang nya persediaan bahan baku yang diminta. Peran sistem informasi akuntansi persediaan bahan baku yang memadai dapat menunjang efektivitas pengendalian internal persediaan bahan baku. Ini didukung oleh terpenuhinya unsur-unsur sistem informasi akuntansi persediaan bahan baku yang memadai dan telah diterapkannya komponen-komponen pengendalian internal dan tercapainya tujuan dari pengendalian internal persediaan bahan baku (Arliyati, 2018).

PT Ciomas Adisatwa Medan merupakan perusahaan yang memproduksi berbagai macam olahan daging menjadi suatu produk yang siap di pasarkan seperti nugget, sosis dan lain-lain. Dalam menjalankan operasi perusahaannya PT Ciomas Adisatwa Medan menggunakan sistem informasi, salah satunya sistem informasi persediaan bahan baku. Sistem yang diharapkan dapat menghasilkan informasi yang cukup atas keputusan persediaan bahan baku berupa daging sapi dan daging ayam.

\section{KONSEP \& TINJAUAN PUSTAKA Kerangka Berpikir}

Kerangka berpikir adalah serangkaian konsep dan kejelasan hubungan antar konsep tersebut yang dirumuskan oleh peneliti berdasarkan tinjauan pustaka, adapun dibawah ini bentuk bagan alur dari sistem informasi akuntansi persediaan. Adapun kerangka yang digunakan penulis dapat dilihat pada gambar berikut:

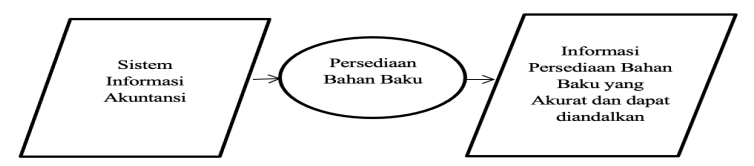

Sumber: Diolah oleh Penulis

Gambar 1. Kerangka Berpikir Penelitian

\section{Hipotesis}

Hipotesis dalam penelitian ini disesuaikan dengan rumusan masalah yang ada, yaitu penerapan sistem informasi akuntansi persediaan bahan baku menghasilkan informasi yang akurat dan dapat diandalkan.Beberapa penelitian yang dijadikan sebagai referensi dalam mengemukan hipotesis ini diantaranya Analisis Sistem Informasi Akuntansi Persediaan Bahan Baku Dalam Kelancaran Proses Produksi (Mustofa et al., 2015), Analisis Sistem Informasi Akuntansi Persediaan Bahan Baku dalam Menunjang Kelancaran Proses Produksi (Putri, 2014), Sistem Informasi Akuntansi Persediaan Bahan Baku menggunakan Metode First Expired First Out (Pratama \& Nurani, 2018) dan Aplikasi Persediaan Barang Menggunakan Metode FIFO Pada CV Bandung Jaya (Harahap, Jamaluddin, \& Lumbantoruan, 2019).

\section{METODE PENELITIAN}

Lokasi Penelitian

Penelitian ini dilakukan di PT. Ciomas Adisatwa yang beralamat di Jl. Besar Klumpang pasar IV, Kec. Hamparan Perak, Kabupaten Deli Serdang, Sumatera Utara 20374.

\section{Jenis dan Sumber Data}

Penelitian yang dilakukan merupakan penelitian kualitatif dengan sumber data yang digunakan bersumber dari PT. Ciomas Adisatwa Medan yang berupa struktur organisasi beserta tugas dan tanggung jawab, prosedur permintaan dan pengeluaran bahan baku beserta penjelasannya. Adapun data sekunder yang digunakan informasi yang didapatkan dari sumber lain seperti laporan dan publikasi yang berkaitan dengan penelitian. 


\section{Analisis Data}

Teknik analisis data yang digunakan pada penelitian ini adalah analisis deskriptif, yaitu teknik yang digunakan untuk mengumpulkan data, mengklasifikasikan data sehingga memberikan gambaran atau keterangan yang berguna untuk membantu mengidentifikasi serta memberikan jawaban atas masalah yang dihadapi.

\section{HASIL DAN PEMBAHASAN Pencatatan Persediaan}

Dalam pencatatan persediaan metode yang digunakan adalah metode mutasi persediaan atau metode perpetual. Metode ini dipakai karena pada akhir bulan diadakan perhitungan fisik sehingga dapat disesuaikan antara pembukuan yang dilakukan oleh bagian gudang dengan hasil perhitungan fisik, dalam metode ini setiap terjadi mutasi persediaan baik itu pembelian maupun pemakaian, oleh bagian gudang akan dicatat dalam buku gudang. Bagian gudang bertanggung jawab atas barang yang ada di gudang, membuat catatan atas semua yang terjadi di gudang.

\section{Prosedur Permintaan dan Pengeluaran Bahan Baku}

Bagian produksi PT. Ciomas Adisatwa melakukan permintaan kepada pihak rumah potong ayam (RPA) dalam pengadaan bahan baku dan ditempatkan di gudang. Berdasarkan jumlah kebutuhan bahan baku, bagian produksi membuat surat permintaan kepada pihak gudang. Proses yang dilakukan PT. Ciomas Adisatwa Medan dalam permintaan dan pengeluaran bahan baku daging di Gudang ditunjukkan pada gambar 2 berikut:

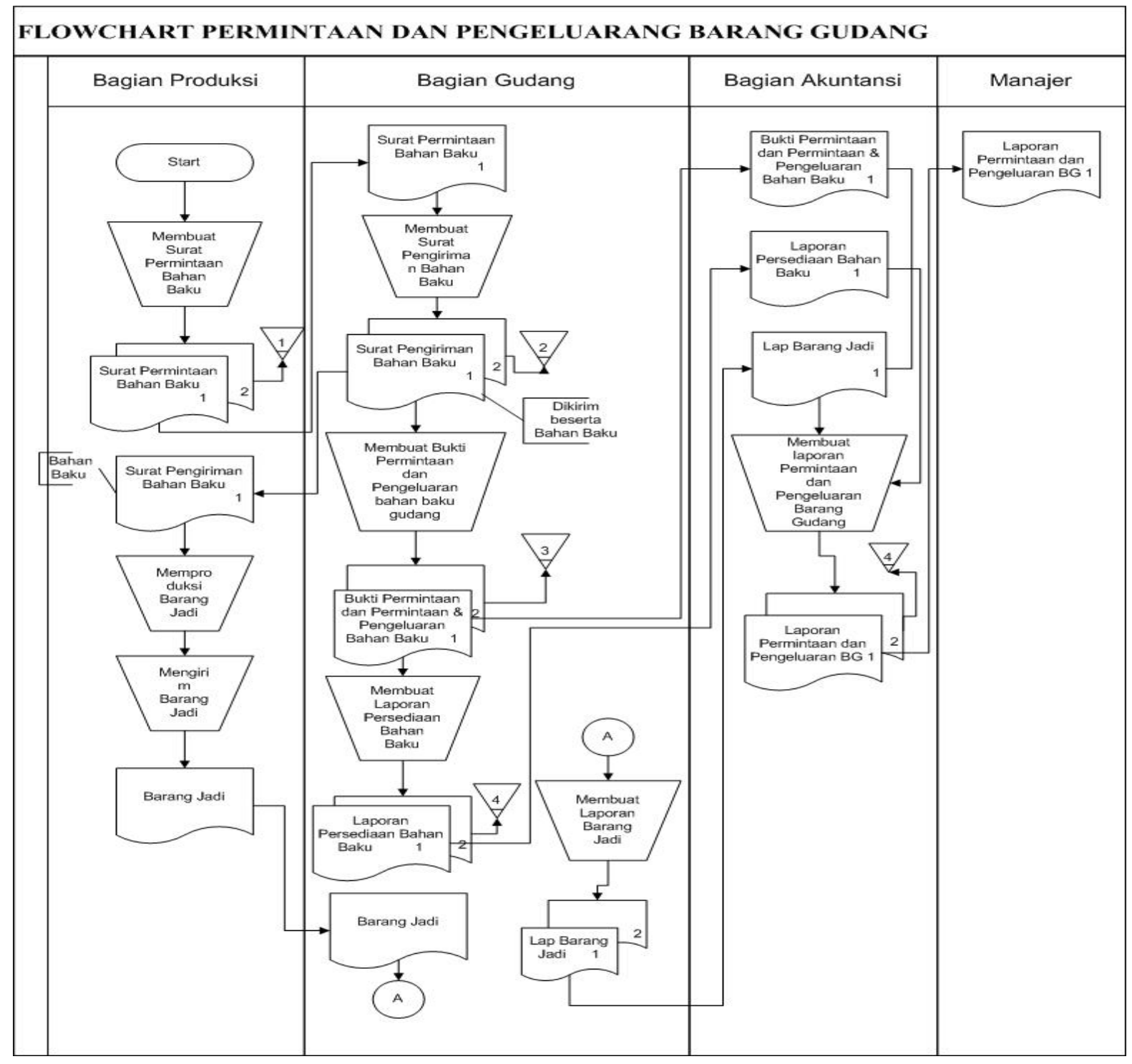

Gambar 2. Flowchart Permintaan dan Pengeluaran Bahan Baku 


\section{Pengendalian Intern dalam Sistem Informasi Akuntansi Persediaan Bahan Baku pada PT. Ciomas Adisatwa Medan}

Pada prosedur permintaan, penerimaan dan pengeluaran bahan baku setiap bagian memiliki fungsi dan tugas masing-masing, yang dilakukan sesuai dengan wewenang masing-masing. Tidak adanya perangkapan tugas yang dapat mengakibatkan terjadinya penyelewengan. Tetapi pihak manajer dalam bagian gudang harus lah mengawasi agar proses pengeluaran barang secara FIFO berjalan dengan semestinya, karena seringnya didapatkan bahan baku daging yang sudah kadaluarsa di bagian penyimpanan gudang. Sering juga terjadi keterlambatan bahan baku yang datang dari gudang bahan baku ke bagian produksi, yang berakibatkan proses produksi menjadi terhambat.

Pengendalian lain yang dilakukan adalah perhitungan fisik persediaan, hal ini dilakukan dengan maksud untuk mengetahui jumlah persediaan fisik barang yang ada di gudang. Dengan perhitungan fisik, dapat diketahui kendala catatan-catatan yang dilakukan oleh bagian gudang maupun staff administrasi pencatatan persediaan. Pengendalian intern dalam sistem informasi akuntansi bahan baku pada PT. Ciomas Adisatwa Medan lebih ditekankan pada perhitungan fisik persediaan bahan baku.

\section{Hasil Analisis}

Dalam sistem informasi akuntansi persediaan bahan baku pada PT. Ciomas Adisatwa Medan terdapat beberapa prosedur yang membentuk sistem yakni penerimaan bahan baku, permintaan bahan baku dan pengeluaran bahan baku.

Pada prosedur permintaan bahan baku, pihak produksi akan memesan bahan baku kepada pihak rumah potong ayam (RPA) dengan cara mengirimkan surat permintaan bahan baku ke pihak RPA sesuai dengan kebutuhan. Setelah itu pihak gudang menerima bahan baku yang dikirim oleh pihak rumah potong ayam, dan pihak gudang mengirim bahan baku ke bagian produksi untuk diolah kembali menjadi barang jadi. Setelah itu pihak produksi membuat bukti atas penerimaan bahan baku. Dari prosedur tersebut dapat disimpulkan bahwa prosedur permintaan, penerimaan dan pengeluaran bahan baku sudah berjalan dengan baik. Karena setiap bagian telah memiliki tugas masing-masing dan tidak terdapat perangkapan tugas.

Pada prosedur pengeluaran barang jadi, bagian produksi mengirimkan barang jadi ke bagian pemasaran yang sudah dikemas dan siap untuk dipasarkan. Bagian produksi akan membuat laporan pengeluaran barang jadi dan di berikan kepada bagian pemasaran dan bagian keuangan. Dalam prosedur pengeluaran barang jadi, dapat disimpulkan bahwa prosedur pengeluaran barang sudah baik. Dikarenakan tidak terdapatnya perangkapan tugas dan setiap bagian memiliki fungsi masing-masing.

\section{KESIMPULAN}

Dari hasil penelitian dapat disimpilkan bahwa dengan penggunan sistem informasi akuntansi persedian pada PT Ciomas Adisatwa Medan bahwa proses permintaan, penerimaan dan pengeluaran bahan baku telah berjalan dengan baik.

\section{DAFTAR PUSTAKA}

Arliyati, J. A. (2018). Pengaruh Sistem Informasi Akuntansi Persediaan Bahan Baku Dan Pengendalian Internal Persediaan Bahan Baku Terhadap Efektivitas Persediaan Bahan Baku (Studi Kasus Pada PT. Mersifarma TM). Universitas Muhammadiyah Sukabumi.

Harahap, E. R., Jamaluddin, J., \& Lumbantoruan, G. (2019). Aplikasi Persediaan Barang Menggunakan Metode FIFO Pada CV Bandung Jaya. Majalah Ilmiah METHODA, 9(2), 74-78.

Mustofa, A. J., Lestari, T., \& Rosyafah, S. (2015). Analisis Sistem Informasi Akuntansi Persediaan Bahan Baku dalam Kelancaran Proses Produksi (Study kasus pada UD. Bintang Terang Surabaya). E-Journal Akuntansi EQUITY, 1(2), $1-10$.

Pratama, F. A., \& Nurani, A. S. (2018). Sistem Informasi Akuntansi Persediaan Bahan Baku menggunakan Metode First Expired First Out. KOPERTIP: Jurnal Ilmiah Manajemen Informatika Dan Komputer, 2(2), 38-49.

Putri, A. D. (2014). Analisis Sistem Informasi Akuntansi Persediaan Bahan Baku dalam Menunjang Kelancaran Proses Produksi (Penelitian pada CV. Second Qartel). Universitas Kristen Maranatha.

Romney, M. B., \& Steinbart, P. J. (2015). Accounting Information Systems (13th ed.). New York: Pearson. 